\title{
Comparison of the Exopeptidase Activity of Fractions from Crude Extracts of Octopus Octopus vulgaris Cuvier Hepatopancreas Using Different Fractionation Methods
}

\author{
Min Ji Kim ${ }^{1}$, Hyeon Jeong Kim ${ }^{1}$, Ki Hyun Kim ${ }^{1}$, Min Soo Heu ${ }^{2}$ and Jin-Soo Kim ${ }^{1 *}$ \\ ${ }^{1}$ Department of Seafood Science and Technology/Institute of Marine Industry, Gyeongsang National University, \\ Tongyeong 650-160, Korea \\ ${ }^{2}$ Department of Food Nutrition/Institute of Marine Industry, Gyeongsang National University, Jinju 660-701, Korea
}

\begin{abstract}
This study was performed to identify the optimum fractionation method and conditions to obtain exopeptidase-active fractions from octopus hepatopancreas (HP) crude extracts (CEs) using four techniques: solid ammonium sulfate fractionation, polyethylene glycol (PEG) fractionation, anion exchange chromatography, and gel filtration chromatography. The fractions with the highest total activity toward L-leucine- $p$-nitroanilide (Leu-pNA) were fraction IV from the ammonium sulfate and PEG fractionation, and fraction II in ion exchange and gel filtration chromatography. The total exoprotease activity of these fractions was highest in fraction IV (4,050.20 U) of ammonium sulfate fractionation, followed by fraction II (3,600.28 U) from gel filtration chromatography, fraction IV (2,861.30 U) from PEG fractionation, and fraction II (2,576.28 U) from ion exchange chromatography. These results suggest that ammonium sulfate fractionation using 60-80\% ammonium sulfate was the most efficient method for separating the exoprotease active fractions from CEs of octopus HP.
\end{abstract}

Key words: Octopus, Octopus vulgaris Cuvier, Octopus hepatopancreas, Exopeptidase, Exopeptidase-active fraction, Enzyme fractionation

\section{Introduction}

In South Korea, octopus is a commonly consumed cephalopod, with an output of 11,398 metric tons in 2010 (Agriculture and Fishery Statistics Department, 2010). The cephalopod has a short life cycle and is characterized by a high growth rate (Hurtado et al., 1999). Because such rapid growth involves a high turnover of proteins, intense proteolytic activity has been found in cephalopod muscle and viscera (Sakai and Matsumoto, 1981). The octopus processing industry generates large amounts of by-products, such as the viscera, skin, and bone, which can have adverse effects on the environment (Souissi et al., 2008). Among these solid by-products, the viscera accounts for $20-40 \%$ of the original material. Therefore, advan- tages exist in converting such viscera waste into resources to extract useful enzymes.

Proteases are the most important industrial enzymes used worldwide, accounting for about $50 \%$ of the total industrial enzyme market (Rao et al., 1998; Bougatef et al., 2007). These proteases are characterized by their mechanism of hydrolysis into endoproteinases or exopeptidases (Guerard, 2007). The breakdown of proteins into peptides is catalyzed primarily by endoproteases such as trypsin, chymotrypsin, pepsin, papain, and elastase, which cleave peptide bonds in protein molecules, usually at specific residues, to produce relatively large peptides (Kristinasson and Rasco, 2000). Exopeptidases such as
(C) 2014 The Korean Society of Fisheries and Aquatic Science This is an Open Access article distributed under the terms of the Creative Commons Attribution Non-Commercial Licens (http://creativecommons. org/licenses/by-nc/3.0/) which permits unrestricted non-commercial use, distribution, and reproduction in any medium, provided the original work is properly cited.
Received 17 December 2013; Revised 20 January 2014 Accepted 05 February 2014

*Corresponding Author

E-mail: jinsukim@gnu.ac.kr 
aminopeptidase and carboxypeptidase then systematically detach the $\mathrm{C}$ - or $\mathrm{N}$-terminal amino acids from the protein or peptide chain. In the food industry, proteases are also used most extensively to improve quality, stability, or solubility in the baking, brewing, and cheese-making industries, as well as meat processing (Haard, 1990; Gupta et al., 2002). However, the enzyme hydrolysates of various proteins frequently exhibit a bitter taste caused by specific peptides (Matoba et al., 1970; Clegg et al., 1974; Bumberger and Belitz, 1993; Izawa et al., 1997), which limits their potential utility in the food industry. Because this bitterness is closely correlated with peptide hydrophobicity (Clegg et al., 1974), several attempts have been made to reduce bitterness by hydrolyzing bitter peptides using exopeptidases (Umetsu and Ichishima, 1988; Minagawa et al., 1989). Although many industrial proteases have been developed, only a limited number of commercial peptidases exist, including aminopeptidase and carboxypeptidase (Deejing et al., 2005).

For the efficient use of exopeptidases from the cephalopod hepatopancreas (HP), extraction, fractionation, and purification procedures must be used. The fractionation process can affect enzyme activity, and in recent years, many studies have been performed to efficiently use cephalopod HPs as a resource for extracting endoproteases (Ezquerra-Brauer et al., 2002; Kim et al., 2007, 2008a) and their inhibitors (Kishimura et al., 2001), as well as exopeptidases (Raksakulthai and Haard, 1999; Raksakulthai et al., 2002; Kim et al., 2008b). However, few studies have assessed the efficient use of octopuses as a resource for extracting endopeptidases and exopeptidases.

In the present study, fractions obtained using various fractionation methods, such as solid ammonium sulfate fractionation, PEG fractionation, anion exchange chromatography, and gel filtration chromatography, were enzymatically characterized to identify the most efficient fractionation method to obtain exopeptidase-active fractions from octopus HPs.

\section{Materials and Methods}

\section{Materials}

The cephalopod HP contains several enzymes. Frozen octopus (Octopus vulgaris Cuvier) HPs were obtained from Kyeongyang Fisheries Co. (Goseong, South Korea) in December 2010 , and stored at $-25^{\circ} \mathrm{C}$ until use.

\section{Chemicals}

Chemicals used to fractionate and collect exopeptidases were purchased from Katayama Chemical Co. (Osaka, Japan) for ammonium sulfate fractionation, Yacuri Pure Chemical Co. Ltd (Kyoto, Japan) for PEG fractionation. Leu-pNA (Sig-
ma-Aldrich Co. St. Louis, MO, USA) and azocasein (SigmaAldrich Co.) were used as the substrates for measuring exopeptidase and endopeptidase activities, respectively. All other chemicals were of analytical grade.

The buffer solutions ( $0.1 \mathrm{M}$ sodium phosphate buffer, $\mathrm{pH}$ 6.0) used to fractionate the crude extracts (CEs) and enzyme reactions were prepared as described previously (Dawson et al., 1986).

\section{Preparation of the crude extracts}

To generate the octopus HP CEs, the frozen octopus HP was partially thawed, and then homogenized with three volumes $(\mathrm{v} / \mathrm{w})$ of deionized water. For enzyme activation, the homogenates were incubated at $20^{\circ} \mathrm{C}$ for $4 \mathrm{~h}$ with stirring for every $30 \mathrm{~min}$ and then centrifuged at $1,200 \mathrm{~g}$ for $30 \mathrm{~min}$ at $4^{\circ} \mathrm{C}$. The CEs were obtained after the supernatants were treated with 0.2 volumes of carbon tetrachloride to remove lipids and centrifuged at $12,000 \mathrm{~g}$ for $30 \mathrm{~min}$ at $4^{\circ} \mathrm{C}$.

\section{Protein concentration}

The protein concentrations of the CEs were measured according to the method of Lowry (Lowry et al., 1951) using bovine serum albumin (Sigma-Aldrich Co.) as the standard. Protein concentration of chromatography for fractionating enzymes was measured at $280 \mathrm{~nm}$.

\section{Endoprotease and exopeptidase activity}

Endoprotease activity was assayed using azocasein as the substrate following the method described by Starky (1977), with some modifications. One-hundred microliters of CE was mixed with $300 \mu \mathrm{L}$ of $1 \%$ azocasein (Sigma-Aldrich Co.) in $1.6 \mathrm{~mL}$ of $0.1 \mathrm{M}$ sodium phosphate ( $\mathrm{pH} 6.0$ ), followed by incubation at $40^{\circ} \mathrm{C}$ for $1 \mathrm{~h}$. The reaction was stopped by the addition of $2 \mathrm{~mL}$ of $5 \%$ trichloroacetic acid (TCA), and the mixture was centrifuged at $146 \mathrm{~g}$ for $15 \mathrm{~min}$. The absorbance of the supernatant was read at $410 \mathrm{~nm}$ and expressed as the endoprotease activity of the sample.

Exopeptidase activities were determined using Leu-pNA (Sigma-Aldrich Co.) as the substrate using a modified version of the method reported by Garcia-Carreno and Haard (1993). One hundred microliters of CE was mixed with 100 $\mu \mathrm{L}$ Leu-pNA in $2 \mathrm{~mL}$ of $0.1 \mathrm{M}$ sodium phosphate buffer $(\mathrm{pH}$ 6.0) and then incubated at $40^{\circ} \mathrm{C}$ for $1 \mathrm{~h}$. The reaction was stopped by the addition of $0.3 \mathrm{~mL}$ of $33 \%$ acetic acid, and the mixture was centrifuged at $146 \mathrm{~g}$ for $15 \mathrm{~min}$. The absorbance of the supernatant was then read at $410 \mathrm{~nm}$.

One unit of endoprotease and exopeptidase activity was defined as the amount of enzyme that increased the absorbance by 0.1 unit per min. Specific activity (U/mg) was defined as the units of activity per mg of protein. 


\section{Fractionation of crude extracts using salt}

The CEs were fractionated using solid ammonium sulfate ranging from $0-20 \%, 20-40 \%, 40-60 \%$, and $60-80 \%$ saturation, and the fractions were collected by centrifugation $\left(12,000 \mathrm{~g}\right.$ for $30 \mathrm{~min}$ at $\left.5^{\circ} \mathrm{C}\right)$. They were then dissolved in a minimum quantity of cold deionized water and dialyzed against deionized water for $24 \mathrm{~h}$ at $5^{\circ} \mathrm{C}$. The dialysates were centrifuged at $12,000 \mathrm{~g}$ for $24 \mathrm{~h}$ at $5^{\circ} \mathrm{C}$, and the supernatants were stored at $-25^{\circ} \mathrm{C}$ until characterization.

\section{Fractionation of crude extracts using polyhydric alcohols}

The CEs were fractionated using PEG concentrations of $0-5 \%, 5-10 \%, 10-20 \%$, and $20-40 \%$, and the fractions were collected by centrifugation at $12,000 \mathrm{~g}$ for $30 \mathrm{~min}$ at $5^{\circ} \mathrm{C}$. They were then dissolved in a minimum quantity of cold deionized water and dialyzed against deionized water for $24 \mathrm{~h}$ at $5^{\circ} \mathrm{C}$. The dialysates were treated and stored as described above in fractionation of CEs using salts.

\section{Fractionation of crude extracts by a difference of ion strength}

A Toyopearl DEAE 650M column $(1.6 \times 20 \mathrm{~cm}$; Tosoh Co. Ltd., Pyungtaek, South Korea) was equilibrated with $10 \mathrm{mM}$ sodium phosphate buffer ( $\mathrm{pH}$ 7.0), and then washed with the same buffer until the conductivity of the eluent and buffer were equal. To obtain exopeptidase-active fractions, the CEs were applied to a column and eluted, and then separated with $110 \mathrm{~mL}$ of an increasing linear $\mathrm{NaCl}$ gradient $(0$, 0.5 , and $1.0 \mathrm{M}$ ) at a flow rate of $30 \mathrm{~mL} / \mathrm{h}$. The protein content (absorbance $280 \mathrm{~nm}$ ) and protease activity (absorbance $410 \mathrm{~nm}$ ) were measured. The exopeptidase-active fractions ( $4 \mathrm{~mL} /$ tube) were treated as described above using different ionic strengths for concentrating and dialysis. The supernatants were stored at $-25^{\circ} \mathrm{C}$ until characterization.

\section{Fractionation of crude extracts according to mo- lecular weight}

A Sephacryl S-300 column $(1.6 \times 100 \mathrm{~cm}$; Pharmacia, Uppsala, Sweden) was equilibrated with $10 \mathrm{mM}$ sodium phosphate buffer ( $\mathrm{pH} 7.0)$, and then washed with the same buffer until the conductivity of the eluent and buffer were equal. To obtain exopeptidase-active fractions, the CEs were applied to the column and eluted, and separated at a flow rate of 12 $\mathrm{mL} / \mathrm{h}$. The protein content (absorbance at $280 \mathrm{~nm}$ ) and protease activity (absorbance at $410 \mathrm{~nm}$ ) were then measured. The exopeptidase-active fractions ( $4 \mathrm{~mL} /$ tube) were collected and centrifuged at 3,000 rpm for $30 \mathrm{~min}$ using an Amicon Bioseparations Centriplus (centrifugal filter devices for volumes up to $15 \mathrm{~mL}$; Millipore, Billerica, MA, USA) for concentration

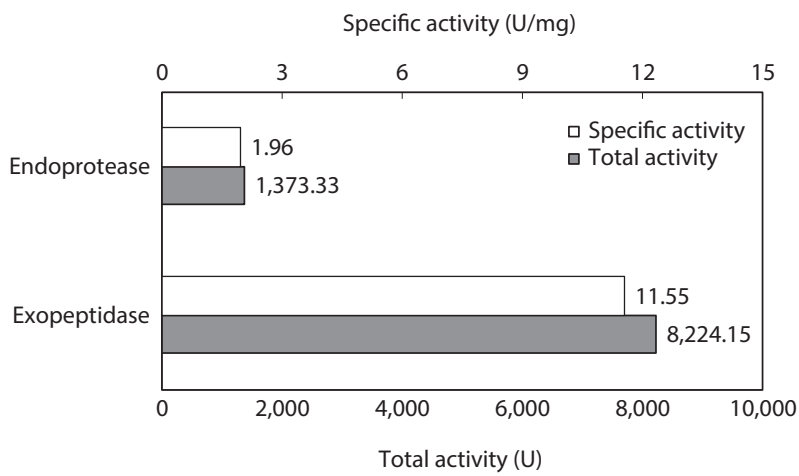

Fig. 1. Comparison on the specific activity $(\mathrm{U} / \mathrm{mg})$ and the total activity (U) toward endoprotease and exopeptidase of the crude extracts from octopus hepatopancreas.

and dialysis. The supernatants were stored at $-25^{\circ} \mathrm{C}$ until characterization.

\section{Results and Discussion}

\section{Comparison of the endoprotease and exopepti- dase activities of the crude extracts}

To examine the potential of octopus HP as a resource for extracting endoprotease- and/or exopeptidase-active fractions, the specific and total endoprotease and exopeptidase activities of the CE fractions were measured and compared (Fig. 1). The specific and total endoprotease activity of the CE was $1.96 \mathrm{U} / \mathrm{mg}$ and 1,373.33 U, respectively, which constituted about $16.7 \%$ of the total exopeptidase activity. Conversely, the exopeptidase activities were $11.55 \mathrm{U} / \mathrm{mg}$ and 8,224.15 U, respectively. These results suggest that octopus HP is a potential superior resource for extracting exopeptidases compared to endoproteases. Kim et al. (2008a, 2008b) reported that the specific exoprotease activity of CEs from Argentinian shortfin squid HPs using Leu-pNA as a substrate was $4.66 \mathrm{U} / \mathrm{mg}$, which is 2.86-times higher than that of endoprotease using azocasein as a substrate of $1.63 \mathrm{U} / \mathrm{mg}$. They concluded that Argentinian shortfin squid HP could be a potential resource for extracting exopeptidases. Taken together, these data suggest that CEs might be useful as a resource for extracting exopeptidases because octopus HP CEs had higher exopeptidase than endoprotease activity.

\section{Optimum fractionation method for obtaining exopeptidase-active fractions}

To assess the optimum fractionation method to obtain exopeptidase-active fractions from octopus HP, the CEs were fractionated consecutively using varying ammonium sulfate concentrations; the fractions were designated fraction I (obtained using 0-20\% ammonium sulfate), II (20-40\%), III 
(40-60\%), and IV (60-80\%). The exopeptidase activity and the yield of octopus HP CE fractions obtained using various ammonium sulfate concentrations are shown in Table 1. The specific exopeptidase activity and purity of fractions from CEs of octopus HP were the highest in fraction I (41.06 U/mg and 3.6-fold, respectively), followed by fractions IV (26.56 U/ $\mathrm{mg}$ and 2.3-fold, respectively), III (16.34 U/mg and 1.4-fold, respectively), and II (5.13 U/mg and 0.4-fold, respectively). This suggests that fractions I and IV contained more purified exopeptidase than the CE, but fractions II and III did not. The purification of exoprotease from the CE was affected by the presence of ammonium sulfate, but was independent of concentration.

Raksakulthai and Haard (1999) reported that the purity and recovery of exopeptidase activity in squid CE (Illex illecebrosus) fractionated using 20-80\% ammonium sulfate was 2.84fold and $34.97 \%$, respectively. Chiou et al. (1988) also reported that the purification and recovery of exopeptidase from CEs of common gray mullet eggs fractionated using 30-60\% ammonium sulfate were 1.1 -fold and $75 \%$, respectively.

The total recovery of exopeptidase activity from CE fractions of the octopus HP was $75.3 \%$. The recovery of exopeptidase activity from fractions III and IV was $21.0 \%$ and $49.2 \%$, respectively, which constituted about $28 \%$ and $65 \%$ of the total recovery, respectively. The total exopeptidase activity of the CE fractions from octopus HP was the highest in fraction IV (4,050.20 U), followed by fraction III (1,726.63 U); fractions II and I had low activities of $<350 \mathrm{U}$. These results suggest that the exoprotease active fraction from the $\mathrm{CE}$ of octopus HP could be fractionated effectively using 60-80\% ammonium sulfate.

Kim et al. (2008b) reported that the exoprotease-active fraction from CEs of octopus HP could be isolated effectively using $30-40 \%$ ammonium sulfate, with a total activity of 2,071.10 U.

To assess the optimum conditions to isolate the exopeptidase-active fraction from octopus HP, the CEs were fractionated using increasing concentrations of PEG. The fractions were designated fraction I (obtained using 0-5\% ammonium sulfate), II (5-10\%), III (10-20\%), and IV (20-40\%).

Exopeptidase activity and the yield of the fractions from CEs of octopus HP obtained using various concentrations of PEG are shown in Table 2. The specific activity and purity of exopeptidase activity was highest in fraction IV $(47.56 \mathrm{U} / \mathrm{mg}$ and 4.1 -fold, respectively), followed by fraction II (38.37 U/ $\mathrm{mg}$ and 3.3-fold, respectively), I (13.21 U/mg and 1.1-fold, respectively), and III (11.69 U/mg and 1.0-fold, respectively). These results suggest that fractions II and IV contained purified exopeptidase activity compared with the CE, whereas the other fractions, such I and III, did not. According to analysis of the specific activity and purity of the fractions, the exoprotease purity from CEs was affected by PEG, but was independent of concentration.

The total recovery of exopeptidase activity in CE fractions of octopus HP was $61.5 \%$; the activity of fraction IV was $34.8 \%$, which constituted about $57 \%$ of the total recovery. The

Table 1. Exopeptidase activities of fractions obtained from the crude extracts of octopus heptapancreas by the ammonium sulfate fractionation toward LeuPNA as a substrate

\begin{tabular}{|c|c|c|c|c|c|c|}
\hline Fraction ${ }^{1)}$ & $\begin{array}{l}\text { Total volume } \\
\text { (mL) }\end{array}$ & $\begin{array}{c}\text { Protein } \\
(\mathrm{mg} / \mathrm{mL})\end{array}$ & $\begin{array}{c}\text { Specific activity } \\
(\mathrm{U} / \mathbf{m g})\end{array}$ & $\begin{array}{l}\text { Total activity } \\
(\mathbf{U})^{2)}\end{array}$ & $\begin{array}{c}\text { Recovery } \\
(\%)\end{array}$ & $\begin{array}{l}\text { Purification } \\
\quad \text { (fold) }\end{array}$ \\
\hline $\mathbf{C E}$ & 50.0 & 14.24 & 11.55 & $8,224.15$ & 100.0 & 1.0 \\
\hline I & 2.6 & 0.78 & 41.06 & 82.30 & 1.0 & 3.6 \\
\hline II & 3.6 & 18.38 & 5.13 & 336.49 & 4.1 & 0.4 \\
\hline III & 4.3 & 24.63 & 16.34 & $1,726.63$ & 21.0 & 1.4 \\
\hline IV & 5.6 & 27.23 & 26.56 & $4,050.20$ & 49.2 & 2.3 \\
\hline
\end{tabular}

${ }^{11} \mathrm{CE}$, crude extracts; I, 0-20\% saturated fraction; II, 20-40\% saturated fraction; III, 40-60\% saturated fraction; IV, 60-80\% saturated fraction. Fraction no. was the same as shown in Fig. 2.

${ }^{2)}$ Total activities (U) were calculated based on the $50 \mathrm{~mL}$ of the crude extracts (CE).

Table 2. Exopeptidase activities of fractions obtained from the crude extracts of octopus heptapancreas by the polyethylene glycol (PEG) fractionation toward LeuPNA as a substrate

\begin{tabular}{ccccrcc}
\hline Fraction $^{\mathbf{1}}$ & $\begin{array}{c}\text { Total volume } \\
(\mathbf{m L})\end{array}$ & $\begin{array}{c}\text { Protein } \\
(\mathbf{m g} / \mathbf{m L})\end{array}$ & $\begin{array}{c}\text { Specific activity } \\
(\mathbf{U} / \mathbf{m g})\end{array}$ & $\begin{array}{c}\text { Total activity } \\
\left.(\mathbf{U})^{\mathbf{2}}\right)\end{array}$ & $\begin{array}{c}\text { Recovery } \\
(\mathbf{\%})\end{array}$ & $\begin{array}{c}\text { Purification } \\
(\mathbf{f o l d})\end{array}$ \\
\hline CE & 50.0 & 14.24 & 11.55 & $8,224.15$ & 100.0 & 1.0 \\
I & 1.7 & 11.07 & 13.21 & 250.11 & 3.0 & 1.1 \\
II & 3.0 & 10.53 & 38.37 & $1,212.26$ & 14.7 & 3.3 \\
III & 3.4 & 18.36 & 11.69 & 736.22 & 9.0 & 1.0 \\
IV & 4.0 & 15.04 & 47.56 & $2,861.30$ & 34.8 & 4.1 \\
\hline
\end{tabular}

${ }^{11} \mathrm{CE}$, crude extracts; I, 0-5\% fraction; II, 5-10\% fraction; III, 10-20\% fraction; IV, 20-40\% fraction. Fraction no. was the same as shown in Fig. 2.

${ }^{21}$ Total activities (U) were calculated based on the $50 \mathrm{~mL}$ of the crude extracts (CE). 
total exopeptidase activity was the highest in the fraction IV (2861.30 U), followed by fraction II $(1,212.26 \mathrm{U})$; other fractions, such as I and III, had low activities of $<750 \mathrm{U}$. These results suggest that the exoprotease active fraction from CEs of octopus HP could be obtained effectively using 10-20\% PEG-based fractionation.

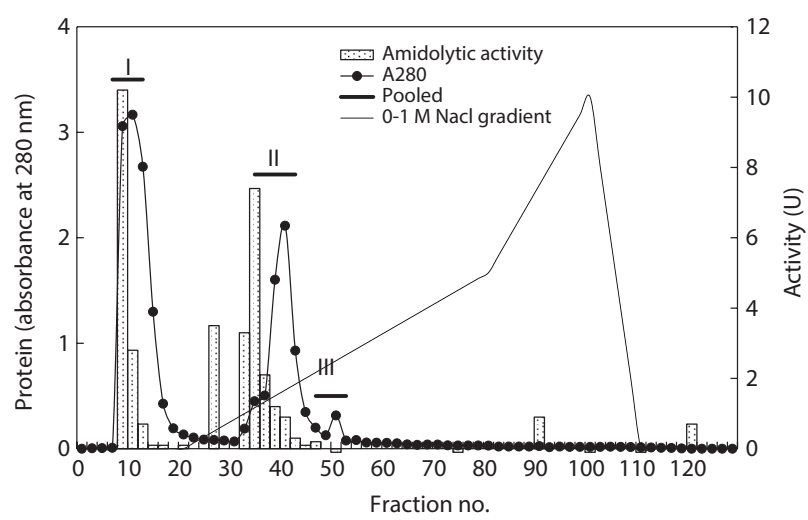

Fig. 2. DEAE-650M ion exchange chromatogram of fractions from the crude extracts (CE) of octopus hepatopancreas (HP). I, concentrates of fraction no. 7-12; II, concentrates of fraction no. 34-42; III, concentrates of fraction no. 46-52. Fraction no. was the same as shown in Fig. 2.

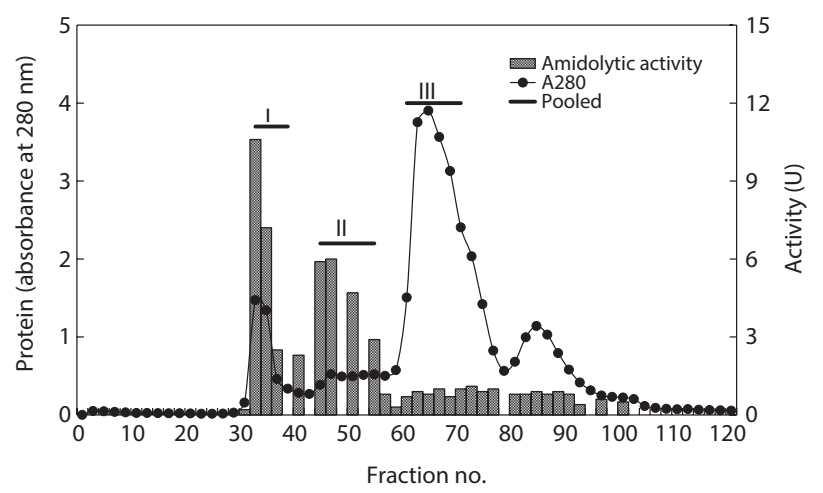

Fig. 3. Gel filtration chromatogram of fractions from the crude extracts (CE) of octopus hepatopancreas (HP). I, concentrates of fraction no. 32-38; II, concentrates of fraction no. 44-54; III, concentrates of fraction no. 60-70. Fraction no. was the same as shown in Fig. 2.
Next, the optimum fractionation conditions using DEAE$650 \mathrm{M}$ anion-exchange chromatography were assessed, and the resulting chromatogram is shown in Fig. 2. Based on the protein concentration and exopeptidase activity shown in the ion exchange chromatogram, these fractions were designated fraction I (a concentrate of fractions 7-12), II (fractions 3442), and III (fractions 46-52). The exopeptidase activity and yield of the CE fractions of octopus HP obtained using ionexchange chromatography are shown in Table 3 . The specific activity and purity was highest in fraction I (33.46 U/mg and 2.9-fold, respectively), followed by fractions III $(32.17 \mathrm{U} / \mathrm{mg}$ and 2.8 -fold, respectively) and II (22.78 U/mg and 2.0-fold, respectively). These results suggest that all fractions obtained using ion-exchange chromatography contained purified exopeptidase activity compared with the $\mathrm{CE}$. The purification of exoprotease from the CE was affected by ionic strength, but was independent of ion strength.

Kim et al. (2008b) reported that an exopeptidase active fraction could be effectively obtained from CEs of Argentinian shortfin squid (Illex argentinus) using ion exchange chromatography-based fractionation; the recovery and purity of fraction II ( $0.2 \mathrm{M} \mathrm{NaCl}$ fraction) using Leu-pNA as a substrate were $10.64 \%$ and 7.41 -fold, respectively.

The total recovery of exopeptidase activity in the fractions was $62.6 \%$; the activity in fractions I and II was $30.3 \%$ and $31.3 \%$, respectively, accounting for about $48 \%$ and $50 \%$, respectively, of the total recovery. The total exopeptidase activity of the fractions was highest in fraction II (2,576.28 U) followed by fraction I $(2,495.61 \mathrm{U})$; fraction III had a very low activity of $81.75 \mathrm{U}$. These results suggest that the exopeptidase-active fraction from CEs of octopus HP could be fractionated effectively by concentrating fractions 7-12 and 34-42 of ion exchange chromatography.

The optimum fractionation conditions to obtain exopeptidase-active fractions from CEs of octopus HP using gel filtration chromatography were assessed using a Sephacryl S-300 resin (Tosoh Co. Ltd). The resulting gel filtration chromatogram is shown in Fig. 3. Based on the protein concentrations and exopeptidase activity, the fractions were designated fraction I (a concentrate of fractions 32-38), II (fractions 44-54), and III (fractions 60-70).

Table 3. Exopeptidase activities of fractions obtained from the crude extracts of octopus heptapancreas by DEAE-650M ion exchange chromatography toward LeuPNA as a substrate

\begin{tabular}{ccccccc}
\hline Fraction $^{1)}$ & $\begin{array}{c}\text { Total volume } \\
(\mathbf{m L})\end{array}$ & $\begin{array}{c}\text { Protein } \\
(\mathbf{m g} / \mathbf{m L})\end{array}$ & $\begin{array}{c}\text { Specific activity } \\
(\mathbf{U} / \mathbf{m g})\end{array}$ & $\begin{array}{c}\text { Total activity } \\
\left.(\mathbf{U})^{2}\right)\end{array}$ & $\begin{array}{c}\text { Recovery } \\
(\mathbf{\%})\end{array}$ & $\begin{array}{c}\text { Purification } \\
(\mathbf{f o l d})\end{array}$ \\
\hline CE & 50.0 & 14.24 & 11.55 & $8,224.15$ & 100.0 & 1.0 \\
I & 22.0 & 3.39 & 33.46 & $2,495.61$ & 30.3 & 2.9 \\
II & 22.0 & 5.14 & 22.78 & $2,576.28$ & 31.3 & 2.0 \\
III & 23.1 & 0.11 & 32.17 & 81.75 & 1.0 & 2.8 \\
\hline
\end{tabular}

${ }^{11} \mathrm{CE}$, crude extracts; I, concentrates of fraction no. 7-12; II, concentrates of fraction no. 34-42; III, concentrates of fraction no. 46-52. Fraction no. was the same as shown in Fig. 2.

${ }^{2)}$ Total activities (U) were calculated based on the $50 \mathrm{~mL}$ of the crude extracts (CE). 
The exopeptidase activity and yield of CE fractions of octopus HP obtained using gel filtration chromatography are shown in Table 4. The specific exopeptidase activity and purity was highest in fraction I $40.34 \mathrm{U} / \mathrm{mg}$ and 3.5 -fold, respectively), followed by fractions II $(26.53 \mathrm{U} / \mathrm{mg}$ and 2.3 -fold, respectively) and III (6.39 U/mg and 0.6-fold, respectively). These results suggest that fractions I and II obtained using gel filtration chromatography contained purified exopeptidase activity, but that fraction III did not. The purity of exoprotease activity was affected by molecular weight and specifically increased with increasing molecular weight.

The total recovery of exopeptidase activity in the fractions obtained using gel filtration chromatography was $71.6 \%$. The recovery in fractions I and II was 25.2 and $43.8 \%$, respectively, which constituted about $35 \%$ and $61 \%$ of the total recovery, respectively. The total exopeptidase activity was highest in fraction II $(3,600.28 \mathrm{U})$, followed by fraction I $(2,071.87$ $\mathrm{U})$; fraction III had very low activity of only $214.06 \mathrm{U}$. These results suggest that exopeptidase activity could be fractionated from CEs of octopus HP by obtaining concentrates of fractions 32-38 and 44-54 using gel filtration chromatography.

\section{Comparison of exopeptidase activity among frac- tions obtained using the different fractionation methods}

Exopeptidase activity and yield of the fractions obtained using the different fractionation methods are shown in Table
5. The fractions with the highest total activity toward LeupNA were fraction IV from the ammonium sulfate and PEG fractionations, and fraction II from ion exchange and gel filtration chromatography. The specific exopeptidase activity and purity was highest in fraction IV from PEG fractionation (47.56 U/mg and 4.1-fold, respectively), followed by fraction IV from ammonium sulfate fractionation $(26.56 \mathrm{U} / \mathrm{mg}$ and 2.3-fold, respectively), fraction II from gel filtration chromatography (26.53 U/mg and 2.3-fold, respectively), and fraction II from ion exchange chromatography $(22.78 \mathrm{U} / \mathrm{mg}$ and 2.0fold, respectively). The total exoprotease activity was highest in fraction IV of ammonium sulfate fractionation (4,050.20 $\mathrm{U})$, followed by fraction II of gel filtration chromatography $(3,600.28 \mathrm{U})$, fraction IV of PEG fractionation (2,861.30 U), and fraction II of anion exchange chromatography $(2,576.28$ $\mathrm{U})$.

These results suggest that ammonium sulfate fractionation using $60-80 \%$ ammonium sulfate is the most efficient method for separating the exoprotease active fractions from CEs of octopus HP.

\section{Acknowledgments}

This research was suppoted by Basic Science Research Program through the National Research Foundation of Korea (NRF) funded by the Ministry of Education, Science and Technology (2010-0021825).

Table 4. Exopeptidase activity of fractions obtained from the crude extracts of octopus heptapancreas by the DEAE-650M anion exchange chromatography toward LeuPNA as a substrate

\begin{tabular}{ccccccc}
\hline Fraction $^{\mathbf{1}}$ & $\begin{array}{c}\text { Total volume } \\
(\mathbf{m L})\end{array}$ & $\begin{array}{c}\text { Protein } \\
(\mathbf{m g} / \mathbf{m L})\end{array}$ & $\begin{array}{c}\text { Specific activity } \\
(\mathbf{U} / \mathbf{m g})\end{array}$ & $\begin{array}{c}\text { Total activity } \\
(\mathbf{U})^{2)}\end{array}$ & $\begin{array}{c}\text { Recovery } \\
(\mathbf{\%})\end{array}$ & $\begin{array}{c}\text { Purification } \\
(\mathbf{f o l d})\end{array}$ \\
\hline CE & 50.0 & 14.24 & 11.55 & $8,224.15$ & 100.0 & 1.0 \\
I & 24.0 & 2.14 & 40.34 & $2,071.87$ & 25.2 & 3.5 \\
II & 18.0 & 7.54 & 26.53 & $3,600.28$ & 43.8 & 2.3 \\
III & 27.0 & 1.24 & 6.39 & 214.06 & 2.6 & 0.6 \\
\hline
\end{tabular}

1) $\mathrm{CE}$, crude extracts; I, concentrates of fraction no. 32-38; II, concentrates of fraction no. 44-54; III, concentrates of fraction no. 60-70.

${ }^{2)}$ Total activities (U) were calculated based on the $50 \mathrm{~mL}$ of the crude extracts (CE).

Table 5. Comparison of exopeptidase activity of fractions from the crude extracts of octopus hepatopancreas obtained by different fractionation methods toward LeuPNA as a substrate

\begin{tabular}{lccccccc}
\hline \multicolumn{1}{c}{$\begin{array}{c}\text { Fractionation } \\
\text { method }\end{array}$} & Fraction & $\begin{array}{c}\text { Total volume } \\
(\mathbf{m L})\end{array}$ & $\begin{array}{c}\text { Protein } \\
(\mathbf{m g} / \mathbf{m L})\end{array}$ & $\begin{array}{c}\text { Specific activity } \\
(\mathbf{U} / \mathbf{m g})\end{array}$ & $\begin{array}{c}\text { Total activity } \\
(\mathbf{U})^{2)}\end{array}$ & $\begin{array}{c}\text { Recovery } \\
(\mathbf{\%})\end{array}$ & $\begin{array}{c}\text { Purification } \\
(\mathbf{f o l d})\end{array}$ \\
\hline- & CE & 50.0 & 14.24 & 11.55 & $8,224.15$ & 100.0 & 1.0 \\
Ammonium sulfate & IV & 5.6 & 27.23 & 26.56 & $4,050.20$ & 49.2 & 2.3 \\
Polyethylene glycol & IV & 4.0 & 15.04 & 47.56 & $2,861.30$ & 34.8 & 4.1 \\
Anion exchange chromatography & II & 22.0 & 5.14 & 22.78 & $2,576.28$ & 31.3 & 2.0 \\
Gel filtration chromatography & II & 18.0 & 7.54 & 26.53 & $3,600.28$ & 43.8 & 2.3 \\
\hline
\end{tabular}

${ }^{1)}$ Fraction IV of ammonium sulfate fractionation, $60-80 \%$ saturated fraction; Fraction IV of polyethylene glycol fractionation, $20-40 \%$ fraction; Fraction II of anion exchange chromatography, concentrates of fraction no. 34-42; Fraction II of gel filtration chromatography, concentrates of fraction no. 44-54.

${ }^{2)}$ Total activities (U) were calculated based on the $50 \mathrm{~mL}$ of the crude extracts (CE). 


\section{References}

Agriculture and Fishery Statistics Department. 2011. Results of the Fishery Production Survey in 2010. Statistics Korea, Seoul, KR.

Bougatef A, Souissi N, Fakhfakh N, Ellouz-Triki Y and Nasri M. 2007. Purification and characterization of trypsin from the viscera of sardine (Sardina pilchardus). Food Chem 102, 343-350.

Bumberger E and Belitz HD. 1993. Bitter taste of enzymatic hydrolysates of casein. I. Isolation, structural and sensorial analysis of peptides from tryptic hydrolysates of beta-casein. Z Lebensm Unters Forsch 197, 14-19.

Chiou TK, Matsui T and Konosu S. 1988. Purification and properties of an aminopeptidase from mullet, Mugil cephalus, roe. Agric Biol Chem 52, 235-242.

Clegg KM, Lim CL and Manson W. 1974. The structure of a bitter peptide derived from casein by digestion with papain. J Dairy Res 41 , 283-287.

Dawson RMC, Elliot DC, Elliot WH and Jones KM. 1986. Data for biochemical research. 3rd ed. Oxford University Press, Oxford, GB, pp. $417-441$

Deejing S, Yoshimune K, Lumyong S and Moriguchi M. 2005. Purification and characterization of hyperthermotolerant leucine aminopeptidase from Geobacillus thermoleovorans 47b. J Ind Microbiol Biotechnol 32, 269-276.

Ezquerra-Brauer JM, Haard NF, Ramirez-Olivas R, Olivas-Burrola $\mathrm{H}$ and Velazquez-Sanchez CJ. 2002. Influence of harvest season on the proteolytic activity of hepatopancreas and mantle tissues from jumbo squid (Doswicus gigas). J Food Biochem 26, 459-475.

Garcia-Carreno FL and Haard NF. 1993. Characterization of proteinase classes in langostilla (Pleuroncodes planipes) and crayfish (Pacifastacus astacus) extracts. J Food Biochem 17, 97-113.

Guerard F. 2007. Enzymatic methods for marine by-products recovery. In: Maximising the Value of Marine By-products. Shahidi F, ed. Woodhead Publishing Ltd, Cambridge, GB, pp. 107-143.

Gupta R, Beg QK, Lorenz P. 2002. Bacterial alkaline proteases: molecular approaches and industrial applications. Appl Microbiol Biotechnolo 59, 15-32.

Haard NF. 1990. Enzymes from food myosystems. J Muscle Foods 1, 293-338.

Hurtado JL, Borderias J, Montero P and An H. 1999. Characterization of proteolytic activity in octopus (Octopus vulgaris) arm muscle. $\mathrm{J}$ Food Biochem 23, 469-483.

Izawa N, Tokuyasu K and Hayashi K. 1997. Debittering of protein hydrolysates using Aeromonas caviae aminopeptidase. J Agric Food Chem 45, 543-545.

Kim HS, Kim JS and Heu MS. 2007. Distribution and extraction condition of endoprotease and exopeptidase from viscera of Illex argen- tinus. J Korean Soc Appl Biol chem 50, 308-315.

Kim HS, Kim JS and Heu MS. 2008a. Fractionation of endoprotease from viscera of the Argentina shortfin squid Illex argentinus. J Korean Fish Soc 41, 176-181.

Kim HS, Kim JS and Heu MS. 2008b. Fractionation of exoprotease from viscera of the Argentina shortfin squid Illex argentinus. J Korean Soc Food Sci Nutr 37, 1009-1017.

Kishimura H, Saeki H and Hayashi K. 2001. Isolation and characteristics of trypsin inhibitor from the hepatopancreas of a squid (Todarodes pacificus). Comp Biochem Physiol B Biochem Mol Biol 130, 117-123.

Kristinsson HG and Rasco BA. 2000. Fish protein hydrolysates: production, biochemical and functional properties. Crit Rev Food Sci Nutr 40, 43-81.

Lowry OH, Rosebrough NJ, Farr AL and Randall RJ. 1951. Protein measurement with the folin phenol reagent. J Biol Chem 193, 265-275.

Matoba T, Hayashi R and Hata T. 1970. Isolation of bitter peptides from tryptic hydrolysate of casein and their chemical structure. Agric Biol Chem 34, 1235-1243.

Minagawa E, Kaminogawa S, Tsukasaki F and Yamauchi K. 1989. Debittering mechanism in bitter peptides of enzymatic hydrolysates from milk casein by aminopeptidase T. J Food Sci 54, 12251229.

Raksakulthai R and Haard NF. 1999. Purification and characterization of aminopeptidase fractions from squid (Illex illecebrosus) hepatopancreas. J Food Biochem 23, 123-144.

Raksakulthai R, Rosenberg M and Haard NF. 2002. Accelerated cheddar cheese ripening with an aminopeptidase fraction from squid hepatopancreas. J Food Sci 67, 923-929.

Rao MB, Tankasale AM, Ghatge MS and Deshpande VV. 1998. Molecular and biotechnological aspects of microbial proteases. Microbiol Mol Biol Rev 62, 597-635.

Sakai J and Matsumoto J. 1981. Proteolytic enzymes of squid mantle muscle. Comp Biochem Physiol 68, 389-395.

Souissi N, Ellouz-Triki Y, Bougatef A, Blibech M and Nasri M. 2008. Preparation and use of media for protease-producing baterial strains based on by-products from cuttlefish (Sepia officinalis) and wastewaters from marine-products processing factories. Microbiol Res 163, 473-480.

Starky P. M. 1977. Elastase and cathepsin G: the serine protease of human neutrophil leukocytes and spleen. In: Proteinases in Mammalian Cells and Tissues. Barrett AJ, ed. Elsevier Science Ltd/NorthHolland Publishing Co., Amsterdam, NL, pp. 57-89.

Umetsu H and Ichishima E. 1988. Mechanism of digestion of bitter peptides from soybean protein by wheat carboxypeptidase. J Jpn Soc Food Sci Technol 35, 440-447. 